\title{
Approaching or Re-thinking the Realm of Criminal Law?
}

\author{
Nicola Lacey ${ }^{1}$ \\ Published online: 9 November 2019 \\ (c) The Author(s) 2019
}

\begin{abstract}
In his latest monograph, The Realm of Criminal Law, Antony Duff gives us a further, magisterial statement of the vision of criminal law, its procedural framework, and its sanctioning system, which he has been developing over the past 35 years. This is Duff's own book-length contribution to the tremendously fruitful collaborative Criminalization project. That project has already generated four edited volumes (Duff et al. in The boundaries of the criminal law, 2010; The structures of the criminal law, 2011; The constitution of the criminal law, 2013; Criminalization: the political morality of the criminal law, 2014) and two fine monographs by Farmer (Making the modern criminal law: criminalization and civil order, 2016) and Tadros (Wrongs and crimes, 2016; see also Tadros in The ends of harm: the moral foundations of criminal law, 2011). It will shape the field for decades to come; and it has decisively laid to rest a longstanding puzzle about why, within criminal law theory, the principles underlying criminalisation had received relatively little attention as compared with those underlying, most obviously, criminal responsibility (cf. Lacey in Frontiers of criminality, 1995).
\end{abstract}

Keywords Criminalization $\cdot$ Criminal law $\cdot$ Responsibility $\cdot$ Punishment $\cdot$ Legal moralism

While The Realm of Criminal Law is informed in different ways by most of Duff's earlier books, its most obvious forebears are Punishment, Communication, and Community (2001) and Answering for Crime (2007). In the former, Duff argued that punishment is best justified as a political community's attempt to 'communicate to offenders the censure they deserve for their crimes' and, 'through that communicative process to persuade them to repent those crimes, to try to reform themselves, and thus to reconcile themselves with those whom they wronged' (Duff 2001: xvii). And in the latter, taking off from a conception of human agency as the capacity to respond to reasons, Duff argued that criminal responsibility is one differentiated

Nicola Lacey

n.m.lacey@1se.ac.uk

1 London School of Economics, London, UK 
normative moment in a distinctive overall social practice of criminalisation. He held that criminalisation, taken as a whole, represents the institutionalisation of one key idea: that of members of a shared political community answering to one another and calling one another to account for alleged wrongdoing. While in the current work punishment is set in the background-as a non-definitional aspect of criminal law-a move which renders Duff's substantial contributions to sentencing theory somewhat oblique to his current vision of the realm of criminal law-the previous themes of communication, censure, political community, and answerability remain key to Duff's vision, while the method of rational reconstruction or interpretation is broadly similar to the practice conception of criminal law theory articulated in Answering for Crime (2007).

The Realm of Criminal Law, however, of course goes well beyond these two previous works, in a number of significant ways. The-purportedly modest-aspiration is to develop not a 'normative theory of criminalization' but rather a 'master principle' - a thin, formal principle that can illuminate the proper basis for particular areas and modes of criminalisation, specifying 'what could give us good reason in principle to criminalize a type of conduct' (p. 3) - a basis that, in contrast with the broadly unitary vision of Punishment, Communication, and Community (2001) is seen in pluralist terms. The master principle inheres in the view that crime must be understood as constituting a distinctive kind of public wrong nested within a conception of civic life that binds citizens together (p. 7). On this conception, a public wrong apt for criminalisation is one that represents a threat to civil order. But within these parameters, many other considerations bear on whether the reasons to criminalisea practice concerned centrally with calling to account rather than with punishment (p. 8)-are stronger than those against criminalisation. So, the master principle sets out a framework for criminalisation in a very broad sense. Where the conduct in question amounts to a public wrong, the master principle sets out a series of further questions that the legislator should ask before deciding to criminalise: how important it is to criminalise that wrong rather than to respond otherwise; to mark the wrong as a wrong, by calling the offender to account for it through a collective and public response leading to a categorical judgement (p. 297). The job of the legislator is accordingly to construct a civic conception of public wrong out of 'pre-legal wrongs' (pp. 302, 311).

This insight lays the groundwork for what Duff terms a modest form of 'thin legal moralism'; for although crimes are distinctive forms of public wrong, criminal law is 'essentially concerned with moral wrongdoing' (p. 52): only conduct that is 'censurably wrong' should be criminalised. And far from seeing the extensive terrain of 'mala prohibita' in instrumental, 'regulatory' terms, Duff claims that even so-called 'regulatory offences' constitute moral wrongs of a distinctive kind: indeed one of the striking features of the book is an extensive, if interstitial, critique of the notion of the view that a part of the terrain of criminal law should be seen in terms of morally neutral 'regulation'. Indeed, in Duff's conception, criminal law is declaratory of pre-legal wrongs rather than-or perhaps, in addition to-being in the business of constructing distinctively legal offences. In a sense, one could say that the only prohibitory norm in Duff's schema-reminiscent of Tony Honoré's (1977) famous argument in his essay 'Real Laws'-is the instruction, 'do not commit criminal 
offences' (see, e.g., pp. 123-125). Moreover it is not clear that he regards this as a legal norm or rather a moral or political norm: criminalisation gives the citizen a reason to obey; a regulatory offence may be 'wrongful only because it is prohibited by the law, [but] the law that prohibits it is not the criminal law' (p. 130).

Other distinctive features of this volume include a far more explicit embrace of republicanism as the background political theory informing the notion of criminal law as defining and proscribing public wrongdoing (cf. Braithwaite and Pettit 1990), generating a conception of civil order as political rather than exclusively moral; an extended and very illuminating analogy between the norms of criminal law as a form of moralised public law and the professional ethics of institutions, such as the legal and medical professions; and a far more extensive development of Duff's response to the evident difficulty for any liberal communitarian theory that the conceptions of value and wrongdoing that inform criminal law may not be universally shared, even among members (I shall have more to say below about Duff's treatment of dissent and of so-called 'recusants'). And, finally, though the modification is attended by no fanfare, Duff appears in this book to have dropped his previous commitment to the proposition that penal censure by definition requires hard treatment (p. 224: cf. von Hirsch 1993; Lacey and Pickard 2015).

In this review article, I will not attempt to assess the full and impressive range of Duff's thinking in The Realm of Criminal Law, but will rather concentrate on three areas in which I find his views less than fully convincing. The first is methodological, and has to do with two ostensibly different but in my view in fact related issues: the way in which Duff's interpretive theory or effort of rational reconstruction conceives its subject matter; and Duff's attitude to interpretive approaches such as Farmer's, Alan Norrie's, or my own, which insist on the relevance of the historical development of the institutional practices and doctrines of criminal law. The second, which in some ways flows from this methodological point, has to do with whether even a modest or thin version of legal moralism can truly capture the distinctiveness of criminal law as a system of social norms in the contemporary systems of England and Wales, Scotland, the United States or indeed other modern states. And the third-again, flowing from what I see as the inappropriateness and even the risks of legal moralism as a way of understanding criminal law-focuses on the way in which Duff's account is embedded within a public philosophy of liberal communitarianism in which citizenship functions as the paradigm of full membership in the criminal law community. Here I ask whether Duff's elaborated analysis of the state's proper response to dissent falls some way short of the aspiration of inclusiveness explicitly envisaged in his earlier work and an underlying theme in this latest book.

\section{Mapping the Realm of Criminal Law}

Duff's book opens with a relatively parsimonious statement of his method of rational reconstruction, and with a decisive rejection of the need to engage with the historical development of criminal legal ideas and institutions in a particular system. $\mathrm{He}$ also rejects the claim (it is not entirely clear to whom this is being attributed) 
that philosophical theorising about institutions such as criminal law starts 'from nowhere' (p. 4). Duff then gives a succinct account of his approach:

The beginnings of our theorizing are ... local or parochial. But that is not to say that we cannot hope to transcend those local beginnings, to engage with a wider 'we' ... Nor is it to say that we must take for granted as an unchangeable given the particular institutions and practices with which we begin. First, we can hope to engage in a process of 'rational reconstruction' of those institutions and practices: to excavate, or (re-)construct, the goals and values by which they purport to be structured; to construct on that basis a theoretical account of what 'our' criminal law claims to aspire to be, and in the light of that account to critically evaluate our existing practices, by way of an 'immanent critique'. (p. 4, footnote omitted)

Duff goes on to suggest that this immanent critique can then be extended by reference to the values similarly implicit in the broader understandings of polity and of civic life in which any system of criminal law is embedded. And he argues that it can be yet further extended beyond the boundaries of a single system so as to engage with other 'localized practices and values ... with which we find that conversation is possible' (p. 4) and from which we may derive inspiration about how further to improve our own system. The core material for this rational reconstruction through which Duff aspires to come to an understanding of criminal law as a distinctive kind of institution is identified as "what I take to be central aspects of "our" Anglo-American systems of criminal law; that I believe is also recognizable in other legal systems, notably those of other contemporary western democracies' (p. 5).

There is a common-sense appeal in Duff's argument. But the more one thinks about it, the more apparent it becomes that this way of delineating the terrain over which the object to be theorised operates leaves an extraordinary amount of latitude to the theorist, inviting the thought that 'prescriptive' or 'aspirational' rather than merely 'rational' reconstruction might be a more accurate way of describing how the method works. In other words, the normative vision that is distilled by the theorist from the vast array of rules, institutional arrangements, and practices involves a process of selection that is itself inevitably shaped by norms and values that are also the ostensible outcome of the process of theory-building. Indeed, this becomes explicit in Duff's further defence of his method and in his admission that his picture does not fit all of 'our existing practices of criminal justice' (p. 20). I continue to think that this sense that practices are sometimes answering to theory rather than the other way around raises important questions about the particular genre of criminal law theory of which Duff is such a gifted exponent; and my view here is reinforced by the rather axiomatic quality of some of the book's more abstract discussion-notwithstanding Duff's assiduousness in providing concrete examples-of criminal law as answerability within a moral community (see, e.g., pp. 111-113). Duff aspires to draw out from the criminal law a core conception that both informs the social practice of criminalisation and generates a normative vision on the basis of which that social practice may be criticised and reformed. Duff argues that any normative theory of criminalisation 'must depend on an account of what criminal law is for', which must in turn 'depend on an account of what criminal law is, what are its distinguishing 
features ...' (p. 10). But if, as is implied by the very method, the object of the exercise is to produce a theory with robust normative credentials, then the theory cannot, by definition, 'answer to' every feature of the practice: some parts of the institutional practice must be jettisoned as unwise, unjustifiable, or incoherent. And in the selection of both features to be emphasised and those to be marginalised or criticised, the normative frame of the theory itself-the vision of what counts as the 'best' interpretation-is implicated. Hence this method is characterised by a certain circularity, and a lack of clarity about the precise balance between explanation, rationalisation, and prescription.

For most criminal law theorists of a moralist stripe, the litmus test for how this methodological issue affects their approach is the significant terrain of strict liability offences. These are all too often marginalised as peripheral, or even ignored, in moralist accounts. To his credit, Duff recognises the existence of these offences in 'our' criminal law, and instead of marginalising them, brings them within the legal moralist fold by insisting that their commission should be regarded as genuinely morally wrong by reference to the overall master principle of criminalisation: viz., these offences have been created because of their impact on civil order, which may on occasion be such as to justify their standing as public wrongs. This is, in my view, both a more honest and a more imaginative take on strict liability offences than the 'marginalise or ignore' strategy. But when I try to enter into Duff's imaginative project and engage in my own process of rational reconstruction, I have to report that I do not find it convincing to interpret the regulatory crime in a 'moralised' way. More convincing to my mind is the sort of view of criminal law emerging from Norrie's (2014), Farmer's (2016; forthcoming), or Chiao's (2019) work, in which the distinctiveness of criminal law as a set of public co-ordinating norms in countries like England and Wales today has been shaped over time by the interplay of ideas, interests, and institutions (see Lacey 2016). Hence the contours, modus operandi, and role of criminal law today is strongly associated with the developing structure and imperatives of governance in, as Chiao puts it, the modern administrative state. This is a view to which I will return in my discussion of Duff's account of regulatory criminalisation in the next section. It is of course an interpretation that comes into view far more readily if we think of criminal law diachronically: as nested within broader institutional structures that have developed decisively over the last 200 years. Seen in this way, the rationale for criminal law as a form of public law is far more distinctive than that in legal moralist accounts, in which, in one way or another, regulatory criminal law is always going to be an outlier, or in need of special explanation.

This judgement may, I think, be reinforced by reference to the fruitful professional ethics analogy that Duff develops and deploys in this book. Codes of professional ethics, Duff argues, carve out a restricted realm of wrongdoing relevant specifically to the res publica of a profession, and are shaped on the basis of a context-relative conception of what is public (pp. 80-82). What is really productive about the analogy is precisely the way in which codes of ethics in professions such as medicine and law embody a distinctive set of norms that underpin the pursuit of potentially valuable and yet potentially harmful social practices, and in doing so express the priorities and aspirations of that practice as understood by its governing body or bodies. But we can surely view such codes in this way without thinking in 
terms of 'thin professional moralism': notwithstanding a substantive overlap with moral norms such as honesty and integrity, the particular contours of professional regulation are driven by the particular goals, needs, and constraints of that professional practice, and are better understood in these discrete terms than as a sub-set of broader moral norms. The analogy with codes of professional ethics, in other words, points us towards the political and the regulatory rather than the moral foundations of criminal law. Indeed, Duff in some ways accepts as much in his conclusion that the restricted understanding of the public implicit in liberal republicanism militates away from the sort of expansive legal moralism adopted by Moore (1997, p. 100); and in some important but undeveloped concessions to Chiao's $(2016,2019)$ and Thorburn's $(2011,2017)$ views (p. 149). In short, I agree with Duff that, as in professional ethics, so in criminal law; but I draw precisely the opposite conclusion from the analogy.

Probably the clearest example of the 'theory in the driving seat' tendency in Duff's current book is, however, his treatment of plea bargaining (pp. 35-36). Again, unlike some ideal theorists inclined to legal moralism, Duff is clear-sighted about not merely the existence but also the extent of plea bargaining. Yet, while acknowledging that a realist might regard his approach as a 'philosophical fantasy' (p. 35), he insists that this reality should not be allowed to displace the centrality of the contested, adversarial trial understood as a calling to account within his overall rational reconstruction of criminal law (p. 30). But can this view really be sustained? Given that the vast majority of cases both in the United States and in the English and Scottish systems are resolved through some form of plea bargain, the question must arise as to whether the trial as a calling to account retains precisely the same place within 'our' criminal law, and of whether any significant institutional change in practice over time would demand adjustment of the interpretive theory of criminal law. This is where, pace Duff's distancing of any need to engage with history from his own methodological view point (p. 3), the bracketing of change over time diverts attention from the way in which criminal law is shaped by its dynamic interactions with both state structures and social cultures: a process that is thrown into sharp relief by a historical (as by a properly comparative) perspective. The growth and institutionalisation of plea bargaining has, in short, changed criminal law in ways that call to be accommodated in any reconstruction of its realm.

Note, too, that my argument that any rational-as opposed to prescriptive or aspirational-reconstruction would have to account for the role of plea bargaining within the criminal law is absolutely consistent with the possibility of a robust critique of plea bargaining in both its substance and its execution. But such a critique must grapple with a large range of questions in political philosophy, notably in relation to the appropriate priorities of modern democratic states in co-ordinating social behaviour and pursuing the public good. Among these would of course be questions about not only the proper extent of criminal law but also the proper scope of fair taxation. In this regard, it is simply not clear to me why Duff questions (p. 4) what space historical or sociologically informed criminal law scholarship leaves for normative theorising. Indeed he himself cites work by both Norrie (2017) and Chiao that establishes the contrary, with Chiao's case for what he calls 'pragmatism' rather than 'formalism' in criminal procedure (Chiao 2019: Chapter 6) an excellent 
example of how such scholarship can both inform and sit comfortably alongside what I have called 'normative reconstruction' (Lacey 1998).

What is at issue here is the relationship between a theory and the phenomena that it seeks to present, rationalise, or justify. A hugely important nexus between prescriptive moral and political philosophy and the phenomena that provide their focus turns on the feasibility of our normative arguments, that typically depend on things like human psychology, the capabilities and responsiveness to reasons or incentives of human beings, the institutional capacities of political systems, and the alignment of interests in particular social contexts. In the philosophical literature on criminal justice, many of the most powerful voices-Duff's among them-make a careful distinction between ideal and non-ideal theory, and temper their conceptions of the latter to what they take to be real-world constraints and conditions. Yet, in this book, the method of rational reconstruction blurs the line between ideal and non-ideal theory, producing a hybrid 'as ideal as possible' theory whose appeal is fundamentally one to shared intuitions about the centrality of certain values. It may be of course that Duff would want to argue — as, at some points, he does - that arrangements such as strict liability and plea bargaining are unjustifiable practices that should be discontinued on the basis that they are incompatible with the normative vision of the criminal process as a species of moral communication between citizens. But, if so, it becomes clear that the boot is very much on the prescriptive or aspirational foot: a vision that excludes so substantial a part of the terrain of contemporary criminal law cannot fairly claim to constitute a 'rational reconstruction'. In my view, Duff's conception of criminal law as a distinctive social institution embodying a distinctive form of civic life-with its tantalising yet undeveloped Wittgensteinian resonance (see, e.g., pp. 87, 160-161)—could have been enriched by a much closer engagement with, say, Farmer's account of the changing priorities and understandings of criminalisation during the course of modern English/Scottish history (Farmer 2016; forthcoming); or with Chiao's (2019) or Thorburn's (2011) accounts of the role of the modern criminal in sustaining co-operation with public institutions or in underpinning governance within a particular constitutional order. Note, too, that the proposition that ideas and ideals have institutional and other conditions of existence is perfectly consistent with the enterprise of normative reconstruction: it simply invites a constructive and open dialogue between such theory and what we know about the world. This is entirely different from the claim that everything reduces to historical contingencies, which undermine the very basis of theorising complex social practices such as criminal law.

\section{Thin Enough Legal Moralism? The Puzzle of Regulation...}

In The Realm of Criminal Law, Duff openly admits the difficulty of reconciling extensive plea bargaining with his legal moralist conception of criminalisation, 'thin' and 'formal' though it may be. It is nonetheless true that his discussion of the matter is relatively brief. According a more central place to a range of procedural arrangements that are commonplaces of what we might call 'everyday criminal law'-the empirical dominance of summary justice or practices of diversion 
from the criminal process, for example-would have made it much harder to present the legal moralist picture-with its paradigm of prosecution and contested trialas a rational reconstruction as distinct from an ideal. The strongly moralised tincture of his overall vision sits, after all, somewhat uncomfortably with the reality of these pervasive features of the contemporary criminal process. Nonetheless, at various points through the book, Duff makes a substantial and original effort to tackle head on the implications of so-called 'regulatory criminal law' for a legal moralist approach. In this section, I will step around the welter of distinctions through which Duff constructs his particular notions of legal moralism (negative vs. positive, exclusive vs. non-exclusive) and his master principle (which he sees as thin and formal yet foundational, exhaustive, exclusive, positive, pro tanto, and primarily responsive rather than preventive (pp. 259-260). Instead, I shall try to piece together Duff's various interventions on this point during the course of the book, and to suggest thatlike the professional ethics analogy - they should lead us away from legal moralism, and not towards it.

On the one hand, not every wrong-not even every public wrong-will call for criminalisation: Duff of course envisages the existence of other forms of regulation, and indeed argues in Chapter 7 that many current forms of criminalisation-notably both certain forms of regulatory strict liability offence and the expanding terrain of pre-emptive offences-have overstepped the proper boundaries marked out by the master principle. He expresses a preference for the institutionalisation of a clear distinction between regulatory infractions and genuinely censure-worthy acts- the German system presents a good example of such a distinction (pp. 16-17) - that are in his view the core terrain of criminal law. Yet he leaves open the door to regarding some regulatory infractions - tax evasion, certain driving offences, and breaches of health and safety norms, for example_as appropriately criminalised (p. 70). This regulatory criminalisation should in his view take place within a distinctive framework governing decisions to prosecute, which should be taken here not on the basis of strict legality but rather of what he calls a discretionary 'principle of opportunity': i.e., the enforcement strategy should prioritise giving offenders maximum opportunities to comply, with criminal enforcement being invoked only as a last resort (p. 29). Hence while regulatory offences are indeed brought within the legal moralist frame-mala prohibita are genuine wrongs that consist simply in 'the breach of a legal regulation that citizens ought to obey' (p. 130)—Duff continues to assert a distinction between 'real' and 'quasi-crime'.

At other points, Duff's statement of what counts as criminal conduct (civic wrong-doing as distinct from harm-causing) is such that it seems inhospitable to a wider range of regulatory offences than those canvassed earlier in the book: 'wrongs that require categorical recognition and condemnation rather than ... nuanced negotiation (and compromise)' (p. 212). Moreover his position on strict liability-which in fact attracts only a handful of references-is somewhat unclear. His initial statement explicitly states that we should object in the strongest terms to liability without fault (perhaps he has in mind here the particular case of 'absolute liability', where even a due diligence defence does not apply (p. 17)). Later on, however, he argues that adjusted burdens of proof and modified fault requirements and penalties, marking out a particular terrain of regulatory violations within ('quasi'-) criminal law, 
may be justifiable within the master principle on the basis of the modified enforcement policy set out above (pp. 284-286). His final position is that such regulatory criminalisation may be justified under the procedural conditions just stated so long as they respond to:

some significant aspect of the polity's common good (the need to guard against the dangers created by driving, or by industrial manufacturing; or to raise revenue for the public purse; or to protect the immature against sexual exploitation); they will appeal to our civic responsibility to contribute appropriately to the (our) common good, and they will show how the regulations are welldesigned to serve that aspect of the common good. (p. 317)

Yet the moralist quality of Duff's theory in effect constitutes mala in se as the paradigm of criminalisation, with all the effort going into the question of how to bring regulatory crime within the moralist frame, rather than investigating in any detail the regulatory quality of the entire terrain of criminal law. To return to the methodological questions posed in the previous section, how would Duff go about persuading us of the superiority of his account, as a rational reconstruction, over, say, Chiao's, with its powerfully argued view that moralism puts the boot on the wrong foot, and turns its back on a profound transformation of criminal law in modern administrative states over the last three centuries (Chiao 2019: Chapter 1)? The question, for example, of whether a prosecution policy should be crafted-à la Braithwaite's influential regularly pyramid (Braithwaite 2002) — on the basis of opportunity far more generally, or of whether institutions such as plea bargaining may have developed in part precisely as strategies geared to maximise the effectiveness of criminal law as a regulatory system quite generally are not directly addressed, with the discussion of Chapter 1.7 somewhat inconclusive as to whether Duff regards the prosecutorial discretion that undoubtedly exists across the English system as consistent with the democratic credentials of criminal law. Moreover, as Duff himself acknowledges in his final reflections on the supposed mala in se/mala prohibita distinction, there is no clear line between these aspects of criminal law, since many offences usually seen as mala in se have regulatory dimensions that cannot be neatly bracketed (pp. 311,313 ). Yet the full implications of this point are not explored; indeed, they cannot be explored within the framework of even a thin legal moralism.

\section{Dealing with Dissent: The Citizenship Paradigm}

Granted that any moral deliberation assumes a set of values that derive from some normative community or other, a key difficulty for any approach aspiring to rationalise criminalisation by appealing to the substance of criminal law appears to be that of identifying a sufficiently rich and shared set of values across the relevant territory and of justifying their imposition on those who either are not members of the relevant community or-as Duff acknowledges they might—utterly reject its values irrespective of their membership status. Citizenship operates as the paradigm of membership in the relevant moral community, with a central reference point in the polity's 'shared values' (pp. 117-118). Duff concedes that a Rawlsian 'overlapping 
consensus' on these values may not exist; and his readers may in any case question the place of such an idea within a master principle that purports to be procedural or formal rather than substantive. Within this vision of a liberal republic organised around solidarity and geared to the common good and to non-dominion (pp. 196-197), citizens are the 'primary addressees' of criminal law (pp. 120-121), but the doctrine of jurisdiction implies that non-members may also be addressed by the law without disrespect. Indeed, Duff advocates an 'inclusionary' concept of citizenship within which, for example, a long-term resident is 'substantially' a citizen, while temporary residents are 'guests', subject to the norms and duties of hospitality (p. 122). But the applicability of criminal law to non-citizens turns not just on a legally specific claim of jurisdiction, but also on the moral basis of the law: on Duff's view, criminal law declares rather than creates wrongs, and where such wrongs are committed within its polity, they are always the law's business.

Even if we allow the (dubious) assumption that dominant values can readily be identified within a pluralistic society, it is not clear, however, that Duff's readers will or should be entirely comfortable with the extent to which his approach, notwithstanding its claim to express a liberal vision, aspires to the internalisation of the dominant community's values, nor that she should be comforted by the suggestion that the offender be invited to express his or her dissent. Readers may also struggle with Duff's suggestion that citizens have a civic duty to play an active part in the trial. This is an example that stretches the boundaries of rational reconstruction given longstanding common law norms such as the privilege against self-incrimination. Conversely, the recent erosion of these norms in the English and Welsh system has been argued to raise normative concerns about the implications for defendants' autonomy (Owusu-Bempah 2017). The historical association of the word 'recusant' with religious dissent is perhaps apt given the moralist quality of Duff's approach, but will add to the discomfort of those like myself who prefer to think of criminal law in political and regulatory terms. Duff's is a painstaking and thoughtful attempt to balance what he sees as the good of civic order and the liberal impulse to toleration and inclusiveness. But it is not clear what space his vision leaves for the important phenomena of resistance and debate in a pluralistic society-phenomena that have, even within the short compass of the last 30 years, brought about fundamental changes in the realm of criminal law in areas such as sexuality or drugs-areas that should sound cautionary notes for the assumptions of legal moralism. And particularly in a world in which the dangers of demonising groups constructed as outsiders-whether because of their migration, ethnic, religious, or political standing — are all too apparent, we should worry about Duff's reluctance to conclude that 'a polity cannot, or ... should not, make full membership as a citizen conditional on the absence of (persistent) criminal behaviour - that it cannot, or should not, exclude at least from full citizenship those who persist in violating its laws' (p. 141).

Granted, Duff accepts that not all citizens will 'see themselves as sharing in the goods that the polity defines as their common good, and see the polity's civil order as their order', but he does see this as 'a necessary aspiration for a polity' (p. 225). And while the recusant's 'rejection of the associative bonds of citizenship' (here the recusant is defined in very stark terms, as someone who does not 'identity the polity's common good as any part of their good' (ibid.)) does not itself undermine 
her citizenship, with the relevant associative obligations, Duff is prepared to canvass offering such recusants 'the option of becoming long-term guests, or resident aliens, rather than citizens' (p. 227) (though at the end of the relevant chapter he reverts to thinking of them as critical citizens (p. 230)). He also emphasises that both the prelegal moral reasons to obey the law and the reach of associative obligations to all within the jurisdiction imply that recusants remain covered by its obligations, albeit as guests or resident aliens. Note, however, that this elaborate argument is itself necessitated precisely by the paradigm status of civic membership, itself reinforced by Duff's (perhaps not so thin) legal moralism; as in the case of his rationalisation of the existence of mala prohibita, the approach is to incorporate what he sees as outlying cases by reference to what he sees as the paradigm, and not to consider whether their scope or importance in fact undermine that paradigm or raise questions about the principles on which it is based. In a pluralist society, is it really appropriate to regard internalisation of shared civic values as a core and necessary aspiration of a decent polity? Vigorous debate and dissent are surely central to any truly open, pluralist society; and this, I would argue, militates against the highly moralised version of political community on which Duff wants his account of criminalisation to rest.

\section{In Conclusion...}

Duff's book is meticulously argued, to a degree that makes it hard for the reader to be confident that she has grasped all the relevant distinctions, and all the nuanced caveats and qualifications (see, e.g., pp. 186-187), in an effort to concentrate on the central elements of his account. I am acutely conscious of having engaged with only a fraction of its comprehensive argument, which spans legal substance and procedure, doctrinal arrangements and their institutional settings, and issues of legal, political, and moral philosophy. For the reasons set out in this article, I cannot follow Duff along the road of legal moralism. But he stands as its most sophisticated and subtle defender; The Realm of Criminal Law consolidates his already towering position in the field.

Acknowledgements My warm thanks go to Maria David, Lindsay Farmer, and Alan Norrie for their very helpful comments on a draft of this paper.

Open Access This article is distributed under the terms of the Creative Commons Attribution 4.0 International License (http://creativecommons.org/licenses/by/4.0/), which permits unrestricted use, distribution, and reproduction in any medium, provided you give appropriate credit to the original author(s) and the source, provide a link to the Creative Commons license, and indicate if changes were made.

\section{References}

Braithwaite, J., 2002. Restorative Justice and Responsive Regulation. Oxford University Press, Oxford. Braithwaite, J., Pettit, P., 1990. Not Just Deserts: A Republican Theory of Criminal Justice. Oxford University Press, Oxford.

Chiao, V., 2019. Criminal Law in the Age of the Administrative State. Oxford University Press, New York. Chiao, V., 2016. What is the Criminal Law For? Law and Philosophy 35(2), 137-163. 
Duff, R.A., 2007. Answering for Crime: Responsibility and Liability in the Criminal Law. Hart Publishing, Oxford.

Duff, R.A., 2001. Punishment, Communication, and Community. Oxford University Press, Oxford.

Duff, R.A., Farmer, L., Marshall, S., Renzo, M., Tadros V. (eds.), 2014. Criminalization: The Political Morality of the Criminal Law. Oxford University Press, Oxford.

Duff, R.A., Farmer, L., Marshall, S., Renzo, M., Tadros V. (eds.), 2013. The Constitution of the Criminal Law. Oxford University Press, Oxford.

Duff, R.A., Farmer, L., Marshall, S., Renzo, M., Tadros V. (eds.), 2011. The Structures of the Criminal Law. Oxford University Press, Oxford.

Duff, R.A., Farmer, L., Marshall, S., Renzo, M., Tadros V. (eds.), 2010. The Boundaries of the Criminal Law. Oxford University Press, Oxford.

Farmer, L., forthcoming. Civil Order, Markets, and the Intelligibility of the Criminal Law, University of Toronto Law Journal.

Farmer, L., 2016. Making the Modern Criminal Law: Criminalization and Civil Order. Oxford University Press, Oxford.

Honoré, A.M., 1977. Real Laws, in Hacker, P.M.S. and Raz, J. (eds.) Law, Morality and Society: Essays in Honour of H.L.A. Hart. Clarendon Press, Oxford, pp. 99-118.

Lacey, N. (ed.), 1998. Normative Reconstruction in Socio-Legal Theory, in Unspeakable Subjects. Hart Publishing, Oxford, pp. 221-250.

Lacey, N., 2016. In Search of Criminal Responsibility: Ideas, Interests, and Institutions. Oxford University Press, Oxford.

Lacey, N., 1995. Contingency and Criminalisation, in Loveland, I. (ed.) Frontiers of Criminality. Sweet and Maxwell, London, pp. 1-27.

Lacey, N., Pickard, H., 2015. To Blame or to Forgive? Reconciling Punishment and Forgiveness in Criminal Justice. Oxford Journal of Legal Studies 35(4), 665-696.

Moore, M.S., 1997. Placing Blame: A Theory of Criminal Law. Clarendon Press, Oxford.

Norrie, A.W., 2017. Criminal Law and Ethics: Beyond Normative Assertion and its Critique. Modern Law Review 80(5), 955-973.

Norrie, A.W. 2014. Crime, Reason and History. Third edition, Cambridge University Press, Cambridge.

Owusu-Bempah, A., 2017. Defendant Participation in the Criminal Process. Routledge, London.

Tadros, V., 2016. Wrongs and Crimes. Oxford University Press, Oxford.

Tadros, V., 2011. The Ends of Harm: The Moral Foundations of Criminal Law. Oxford University Press, Oxford.

Thorburn, M., 2017. Punishment and Public Authority, in du Bois-Pedain, A., Ulväng, M., Asp, P. (eds.) Criminal Law and the Authority of the State. Hart Publishing, Oxford, pp. 7-35.

Thorburn, M., 2011. Criminal Law as Public Law, in Duff, R.A., Green, S.P. (eds.) Philosophical Foundations of Criminal Law. Oxford University Press, Oxford, pp. 21-43.

von Hirsch, A., 1993. Censure and Sanctions. Clarendon Press, Oxford.

Publisher's Note Springer Nature remains neutral with regard to jurisdictional claims in published maps and institutional affiliations. 